\title{
研究
}

\section{水晶摩擦真空計の高精度・高機能化 データ処理の研究*}

\author{
小林 太吉**.北條 久男**
}

（受理1993年 9 月 16 日，掲載決定1994年 3 月 5 日）

\section{Digital Data Processing for Quartz Friction Vacuum Gauge \\ Takichi KOBAYASHI and Hisao HOJO}

(Vacuum Products Corporation, 1-1 Honcho 4-chome, Koganei-shi, Tokyo 184, Japan)

(Received September 16, 1993, Accepted March 5, 1994)

The pressure dependence of resonance impedance of a wristwatch oscillator made it possible to estimate ambient gas pressures from $1 \mathrm{~atm}$ to $1 \mathrm{~Pa}$. A thermometer-type oscillator provides a practical basis for compensating thermal variation of the intrinsic impedance and lowers the minimum detectabale pressure to $10 \mathrm{mPa}$. Based on the theory of the gauge, a digital data processing method was developed for an 8-bit microprocessor to realize automatic pressure indication with errors of less than around $10 \%$ in a full pressure range for any gas with given values of mass and viscosity constant. By utilizing the pressure dependence of the resonance frequency and the impedance, automatic discrimination of hydrogen from air was successfully demonstrated.

\section{1. はじめに}

我々は，水晶振動子の共振インピーダンスが気体の摩 擦による抗力によって, 分子流領域では圧力の 1 乗に比 例し，粘性流領域では圧力の $1 / 2$ 乗に比例する特性が理 論的に裏付けされていることに着目し ${ }^{3)}$, 高感度高機能 真空計の開発を進めてきた ${ }^{2,3)}$.として, 腕時計用の小 型水晶振動子に代えて，ほぼ同じ形状で結晶方位の異な る新しいタイプの振動子を用いて, その周波数変化から 振動子自体の温度を計測して，固有インピーダンスの温 度変化を補償すれば，実効的な可測圧力の下限を約 1 $\mathrm{Pa}$ から $1 \times 10^{-2} \mathrm{~Pa}$ へと改善できることを実証した4).

本研究では, 圧力による共振インピーダンス変化の気 体種依存性を理論式に基づいて計算するマイクロプロセ ッサー用データ処理法, 並びに，固有インピーダンスの 温度変化に対応する自動補正法を開発した。これらによ

* 平成 4 年 10 月 30 日 第33回 真空に関する連合講演で講演

** バキュームプロダクッ株式会社（テ184 東京都小金井市本町 4-1-1）
り, 分子量と粘性係数を与えれば原理的にはいかなる気 体種に対しても大気圧から $1 \times 10^{-2} \mathrm{~Pa}$ までの実効圧力 を表示できる実用真空計の基本となる技術が確立した。 さらに, この真空計では, 原理的に感度の低い軽質量気 体の真空装置への導入時に起きうる過圧を未然に防ぐ機 能の付加にも成功した.

\section{2. 真空計の構成}

Fig. 1 は音叉型水晶振動子の構造模式図, Fig. 2 は本 真空計の電気回路構成を示す図である. 電流電圧変換 器, 電圧制御減衰器, $1 / 10$ 減衰器および比較器とによっ て定電圧駆動形の自励発振回路を構成し, 水晶振動子を $100 \mathrm{mV}$ ピーク値の一定電圧で駆動している. 電流電圧 変換器の出力振幅は水晶振動子の共振インピーダンス （Z）に反比例する。これを直流として16 bit 分解能の $\mathrm{A} / \mathrm{D}$ 変換器でデジタル值に变換し, CPUに取りこむ. そして演算によって共振インピーダンス $(Z)$ とインピ 一ダンス変化量 $\Delta Z\left(=Z-Z_{0}\right)$ とを求めている.ここで $Z_{0}$ は振動子自身の固有インピーダンスである. 水晶振 
動子の共振周波数は周波数カウンターによって計数され, CPUに取りこまれる。そしてメモリ一に記録してある 周波数と温度との対照表を用いた演算によってセンサー 温度が求められ, その温度の值から $Z_{0}$ の補正量が計算 され，センサー温度変化に対する補正が抗こなわれる。

\section{3. 新しい圧カセンサー}

腕時計用の振動子を用いたこれまでの水晶真空計は感

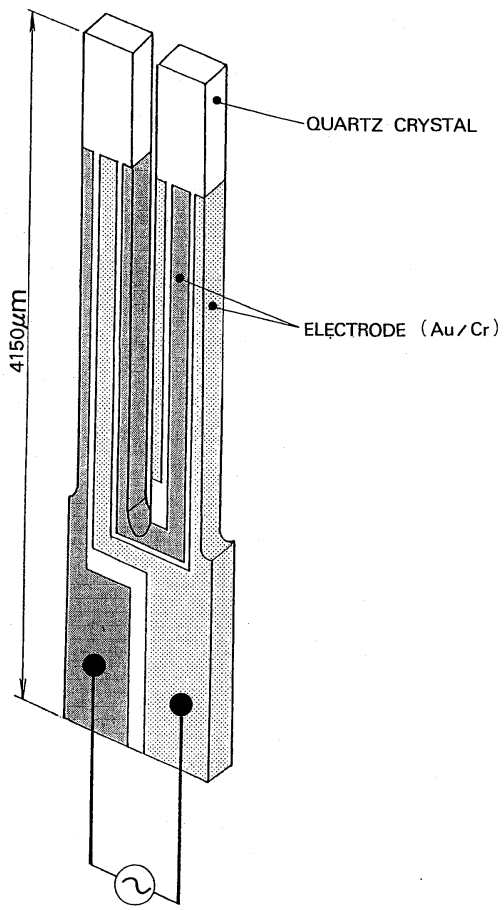

Fig. 1. Configuration of the thermometer-type oscillator.
度，振動子固有のノイズ，そして周囲温度によるインピ 一ダンス変化等の影響のため, 圧力測定下限は約 $1 \mathrm{~Pa}$ （恒温槽型で0.1 Pa）が限界であった

測定圧力範囲のより低圧側への拡張と高精度化, およ び温度補償を精度良く行う目的で新しいセンサーを使用 した。

高感度, 高精度化には，振動子自身の電気的，機械的 損失の低減，振動子の寸法あるいは気体の摩擦効果によ るインピーダンス変化の大きい結晶方位の選択等が考兵 られる.インピーダンス変化に及ぼす振動子の形状の影 響については，振動部を細長くすることで測定圧力下限 をより低圧側に拡張できることはすでに報告されてい る ${ }^{3,7,8)}$. しかし，振動部を細長くすることにより測定時 定数が長くなることや外部振動の影響を受けやすいなど 実用的には問題がある.

今回使用した振動子のサイズは，測定時定数や外部振 動の影響を考慮して時計用とほぼ同じであるが， $Z$ 板を 基準として，X軸を回転軸として結晶方位を一 $15^{\circ} \sim$ $-30^{\circ}$ 回転した水晶板から形成したものである.

Fig. 3 は温度に対する振動子の共振インピーダンス $\left(Z_{0}\right)$ と共振周波数（ $f$ ) の関係を示す測定データであ り, $f$ が温度に対して比例（腕時計用は 2 次曲線特性） する温度センサーの機能をもっていることが解る.

Fig. 4 は圧力 $<1 \times 10^{-4} \mathrm{~Pa}$ で, 温度 $20 \pm 0.1^{\circ} \mathrm{C}$ に打け る振動子自身のインピーダンス $Z_{0}$ の変動を記録した結 果を示し, $Z_{0}$ の変動は圧力換算で $1 \times 10^{-3} \mathrm{~Pa}$ 程度とな り時計用に比べて約 $1 / 50$ ノイズレベルを低減できた。

Fig. 5 はインピーダンス変化量 $\Delta Z\left(=Z-Z_{0}\right)$ と圧力 の関係を示す， $\Delta Z$ はいずれの気体についても低圧で圧 力に比例し, 大気圧付近では圧力の $1 / 2$ 乗で増加し, 中 間の圧力で圧力依存性が徐々に小さくなる特性を示して

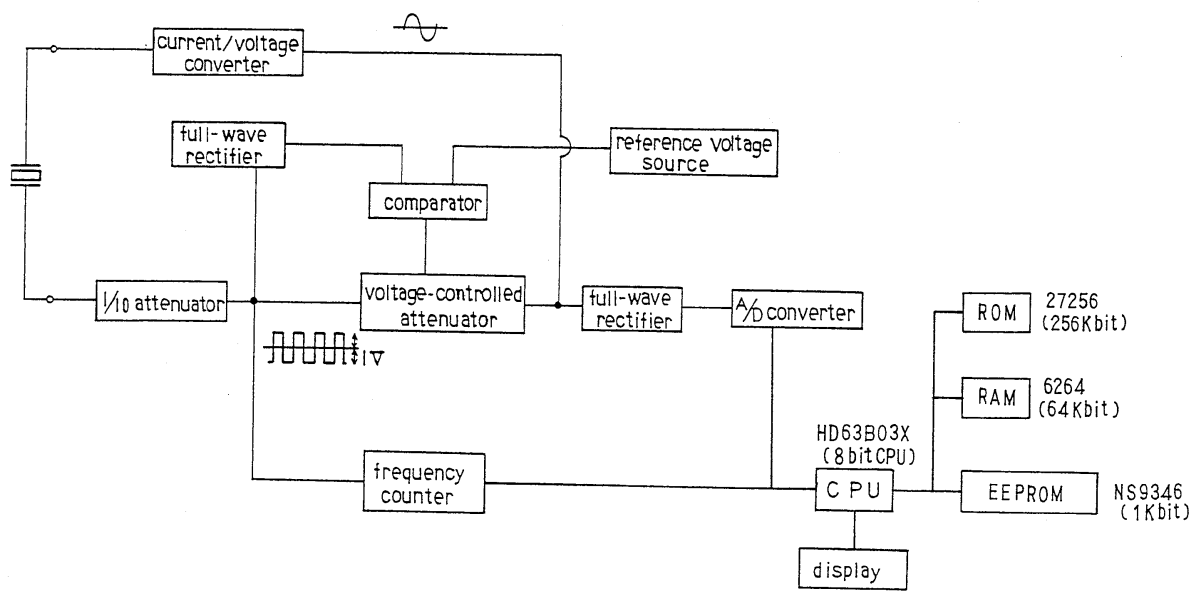

Fig. 2. Circuit diagram of the quartz friction vacuum gauge. 


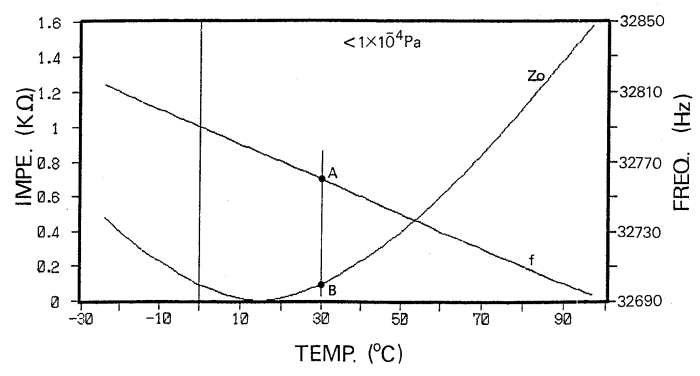

Fig. 3. Temperature dependence of the intrinsic impedance $Z_{0}$ and resonance frequency measured for the themometer-type oscillator.

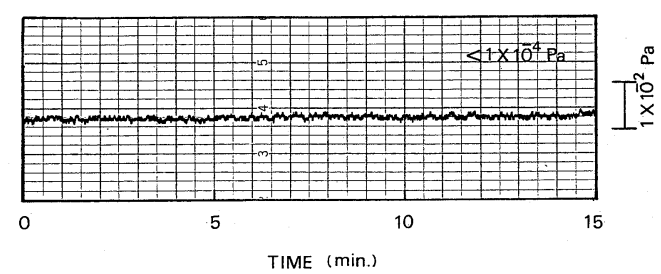

Fig. 4. Fluctuaition of the intrinsic impedance $Z_{0}$ at constant temperature under a pressure of less than $1 \times 10^{-4} \mathrm{~Pa}$.

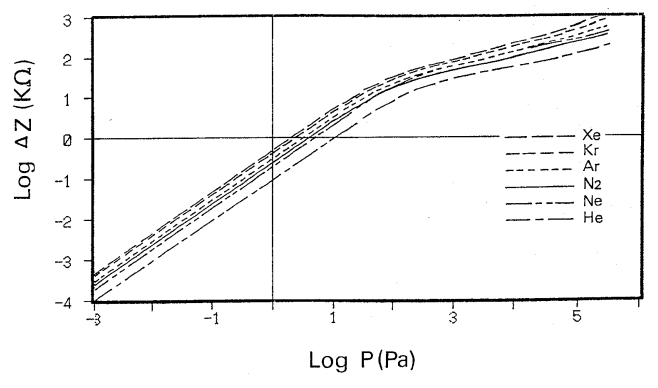

Fig. 5. Pressure dependence of the impedance increment $\Delta Z$ for six gases.

打り従来の時計用と同じ特性である。

\section{4. 温度補 償}

振動子の共振インピーダンス $Z_{0}$ の温度特性は Fig. 3 の如 $<15^{\circ} \mathrm{C}$ 前後で最小値となる 2 次曲線となり, 広い 温度範囲で $\pm 1 \mathrm{k} \Omega$ 程度変化する. 従って Fig. 5 の $1 \mathrm{~Pa}$ 以下 $(\Delta Z か ゙ 100 \Omega$ 以下) では温度によるインピーダン ス変化が測定値に大きく影響する。

$Z_{0}$ の温度による変化を小さくするために振動子を七 一ター, 温度センサーとともにアルミニウムに埋め込み 振動子を一定温度（ $50^{\circ} \mathrm{C} ）$ に保持できるよらにした 測定子が報告され実用化されてる5 .しかしながら，こ

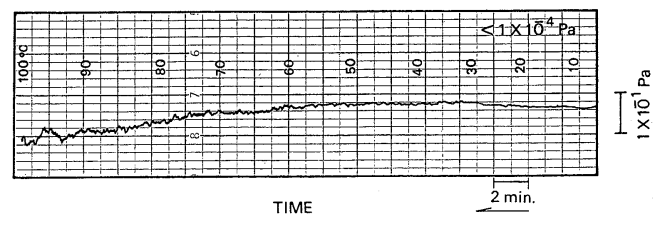

Fig. 6. Change in the intrinsic impedance $Z_{0}$ with thermal compensation during temperature variation from 10 to $60^{\circ} \mathrm{C}$.

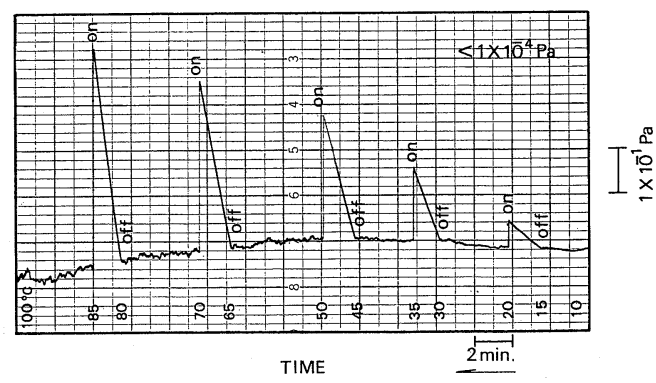

Fig. 7. Variation of the intrinsic impedance $Z_{0}$ due to switching of the thermal compensation function. The pressure and temperature are the same as in Fig. 6.

の方式では温度変化に対しての応答が遅く, またヒータ 一温度を一定に保つための制御回路が必要となる。

本真空計では Fig. 3 の共振周波数特性を利用して振 動子自身の温度（例兄ば，Fig. 3 A 点に対応する温度） を正確に検出し, その時の温度による共振インピーダン スの変化分（Fig. 3 B 点の値）を用いて測定值を補正す る事によって温度補償を行ら方式とした。 センサー発振 周波数を計数する事により毎秒 1 回センサー温度を $0.03^{\circ} \mathrm{C}$ の分解能で計算し, $Z_{0} を 0.2 \Omega$ 程度の分解能で補 償する.これは $N_{2}$ に対して約 $1 \times 10^{-3} \mathrm{~Pa}$ の圧力分解能 での補償が可能なことになる。

チャンバー内圧力を $1 \times 10^{-4} \mathrm{~Pa}$ 以下に保ち，センサ 一温度を $10^{\circ} \mathrm{C} \sim 100^{\circ} \mathrm{C}$ まで連続的に变化させた時の本真 空計圧力指示变化を Fig. 6 に示す. 同じような連続的 温度変化時に温度補償機能を入切した時の圧力変化を Fig. 7 に示す.

Fig. 6 亿おいて振動子温度の $10^{\circ} \mathrm{C}$ から $60^{\circ} \mathrm{C}$ への変化に 対する圧力指示值の変化は $2 \times 10^{-2} \mathrm{~Pa}$ である. 温度補 償なしではこの温度变化によって測定される振動子共振 インピーダンスが $0.6 \mathrm{k} \Omega$ 程度変わるので圧力指示は 4 $\mathrm{Pa}$ 程度まで上昇してしまう。従って，本真空計で用い た温度補償によって温度ドリフトが $1 / 100$ 以下に小さく なった事になる。振動子温度が $70^{\circ} \mathrm{C}$ を超えると温度補 


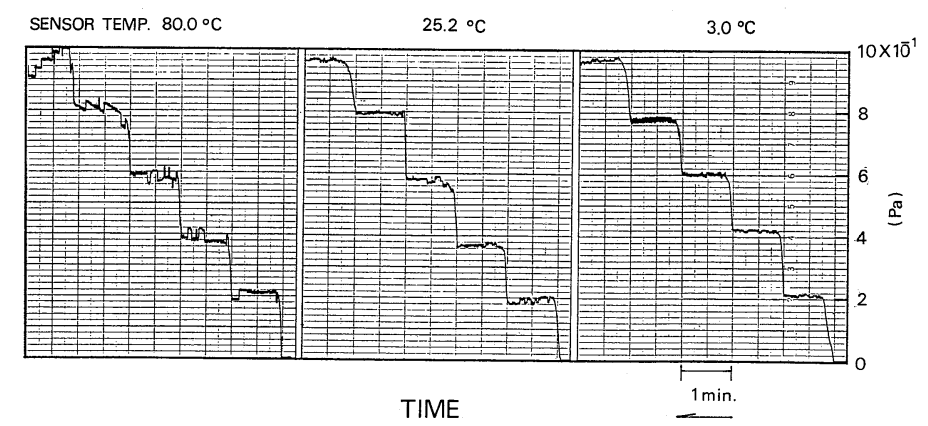

Fig. 8. Variation of the pressure indication during stepwise pumping down for different gauge temperatures.

償の䛊差, すなわち振動子共振インピーダンス变化と測 定した共振周波数から計算した真空計の自動補償の差が

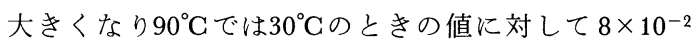
$\mathrm{Pa}$ 程度圧力指示が低下する。これは温度に対する振動 子共振インピーダンス特性（Fig. $3 Z_{0}$ ) が $70^{\circ} \mathrm{C}$ 以上で振 動子間の特性のバラッキが大きいためである.

Fig. 7 亿おいてて温度補償を切った時急汇圧力指示值が 上昇しているが，これはFig. 3 の共振インピーダンス の温度変化がそのまま圧力指示值に反映している事にな る. 本真空計では温度補償を切った時も補償量は記憶さ れているので補償が入れば元の圧力值に戻る.

センサー温度 $3.0^{\circ} \mathrm{C}, 25.2^{\circ} \mathrm{C}, 80.0^{\circ} \mathrm{C}$ のきチャンバー 内圧力を $2 \times 10^{-1} \mathrm{~Pa}$ ステップで変化させたときの真空 計の圧力指示値の変化を Fig. 8 に示す. $80.0^{\circ} \mathrm{C}$ におけ る圧力指示値の段階的变化は本温度補償の温度測定分解

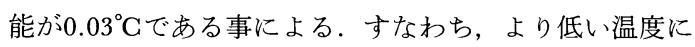

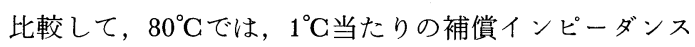

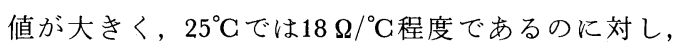
$80^{\circ} \mathrm{C}$ では約 2 倍の $40 \Omega /{ }^{\circ} \mathrm{C}$ と大きなるためでる。これ に対してはメモリ容量の増大などによる計算精度の向上 によって改善することは可能であるが, 実用真空計とし ては価格対性能比を考慮して現状の特性とした，本温度 補償機能によりセンサー温度 $10^{\circ} \mathrm{C}$ から $60^{\circ} \mathrm{C}$ の範囲内で は圧力測定下限が $1 \times 10^{-2} \mathrm{~Pa}$ まで拡大された事を実験 的に確認することができた。

\section{5. 各種気体に対する感度校正}

水晶振動子の圧力と共振インピーダンスの関係は理論 的に確立されて招り, 全圧力領域に和ける共振インピー ダンス変化量 $\Delta Z$ と圧力の関係は次の統一式で記述され る1).

$$
\Delta Z=C\left(6 \pi \eta^{\prime} R+3 \pi R^{2} \sqrt{Z \cdot \eta^{\prime} \rho \omega}\right)
$$

$$
\eta^{\prime}=\eta \frac{1}{1+\frac{\zeta}{\varepsilon R}}, \quad \zeta=\frac{\eta}{P} \sqrt{\frac{\pi R_{0} T}{2 M}}
$$

$$
\begin{array}{lll}
\eta^{\prime}: \text { 見かけの粘性率 } & \eta: \text { 粘性率 } \\
\varepsilon & : \text { 数因子 } & \xi: \text { すべり係数 } \\
R: \text { 振動子の厚み } & \rho: \text { 密度 } \\
\omega & : \text { 共振周波数 } & C: \text { 比例定数 }
\end{array}
$$

今回使用した振動子も(1) 式と実験值とが非常に良く 一致する.

我々は実用的な真空計に適用するために真空計で測定 している $\Delta Z$ から圧力值を, 通常使用するのに十分な計 算速度で求めるために(1) 式を $P=f(\Delta Z)$ の形に変形す るとともに, 分子流・中間流と粘性流との 2 つ領域で の圧力值を連続的に接続することを試みた.

\section{1 分子流・中間流領域}

この領域では，(1)式右辺第 2 項は第 1 項と比べて小 さく，無視できるので同式は(3)式とみなせる.

$$
\Delta Z=C \cdot 6 \pi \eta \frac{1}{1+\frac{\zeta}{\varepsilon R}} R
$$

この (3)式を $P=f(\Delta Z)$ の形に変形すると(4)式となる.

$$
P=K_{3} \frac{\Delta Z}{1-K_{4} \Delta Z}
$$

ここで

$$
\begin{aligned}
& K_{3}=\frac{1}{C \cdot 6 \pi R^{2} \cdot \varepsilon} \sqrt{\frac{\pi R_{0} T}{2 M}} \\
& K_{4}=\frac{1}{C \cdot 6 \pi R \eta}
\end{aligned}
$$

$K_{3}$ は $1 /(M)^{1 / 2}$ に比例し, また $K_{4}$ は $1 / \eta$ に比例する值 である。

\section{2 粘性流領域}

圧力の高い粘性流領域では $\eta^{\prime}$ と $\eta$ は一致する. 従っ て(1)式の $\eta^{\prime}$ を一定值 $\eta$ で置き換えることができるので 
（7）式となる.

$$
\Delta Z=C\left(6 \pi \eta R+3 \pi R^{2} \sqrt{2 \eta \rho \omega}\right)
$$

ここで

$$
\rho=\frac{M}{R_{0} T}
$$

$P=f(\Delta Z)$ の形に変形すると $(9)$ 式となる.

$$
\begin{aligned}
P & =\left(\frac{\Delta Z-K_{1}}{K_{2}}\right)^{2} \\
\text { ここで } & \\
K_{1} & =C \cdot 6 \pi \eta R \\
K_{2} & =\sqrt{\frac{2 \eta M \omega}{R_{0} T}} 3 \pi R^{2} \cdot C
\end{aligned}
$$

$K_{1}$ は $\eta$ に比例し, $K_{2}$ は $(\eta \cdot M)^{1 / 2}$ に比例する值である.

\section{3 全圧力領域}

分子流・中間流領域及び粘性流領域において, 共振イ ンピーダンス $\Delta Z$ から圧力值 $P$ を求める近似式を導出し たが近似が粗いので, $K_{1}, K_{2}, K_{3}, K_{4} に(1)$ 式と同じ数值 を導入しても中間流領域で 2 つ領域の式 (4)，(9) が接 続しない.Fig. 9 はXeと $\mathrm{Ne}$ の場合を示す。このよう な不連続の問題を解消するために我々は分子流領域及び 粘性流領域では (4)，(9) 式と実験值が非常に良く一致す ることに立脚して中間流領域のみに影響する (4) 式の $K_{4}$ を変化させ，(4)，(9)式を連続させることを試みた。

(4) 式と (9) 式が連続するとすれば, 両式の接続点で次式 が成立する。

$$
\frac{K_{3} \cdot \Delta Z}{1-K_{4} \cdot \Delta Z}=\left(\frac{\Delta Z-K_{1}}{K_{2}}\right)^{2}
$$

整理すると

$$
\Delta Z^{3}+3 b \Delta Z^{2}+C \Delta Z+d=0
$$

ここで

$$
b=-\frac{1+2 K_{1} \cdot K_{4}}{3 K_{2}}
$$

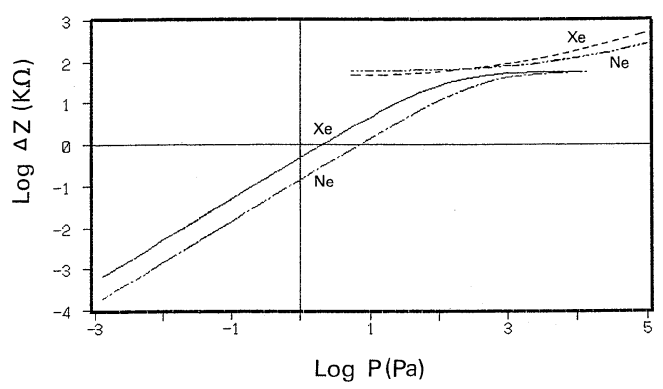

Fig. 9. Pressure dependence of the impedance increment $\Delta Z$ for $\mathrm{Xe}$ and $\mathrm{Ne}$ calculated using equations (4) and (9).

$$
\begin{aligned}
& C=\frac{2 K_{1}+K_{1}^{2} K_{4}+K_{2}^{2} K_{3}}{K_{4}} \\
& d=-\frac{K_{1}^{2}}{K_{4}}
\end{aligned}
$$

3 次方程式における cardanoの公式により

$$
\gamma=b^{2}-C / 3
$$

と执くと

$$
\begin{array}{ll}
q=\frac{b C-3 b^{2}-d}{2} \\
q^{2}-\gamma^{3}<0 & \text { 実数解 } \\
q^{2}-\gamma^{3}=0 & \text { 重 解 } \\
q^{2}-\gamma^{3}>0 & \text { 解なし }
\end{array}
$$

Fig. 10にこの関係を図示した。 ここで $a$ は $q^{2}-\gamma^{3}>0$ に対応する曲線, $b$ は $q^{2}-\gamma^{3}=0$ に対応する曲線 $c$ は $q^{2}$ $-\gamma^{3}<0$ に対応する曲線である。分子流領域のカーブと 粘性流領域のカーブが接しない場合は曲線 $a$ に対応す る. 従って $q^{2}-\gamma^{3}=0$ となるような $K_{4}$ を求めれば分子 流領域の曲線と粘性流領域の曲線とが接して連続性を確 保できる. $q^{2}-\gamma^{3}=0$ の条件を満たす $K_{4}$ を求める場合, $q^{2}-\gamma^{3}=0$ の式で直接演算する方法と $q^{2}-\gamma^{3}<0$ で $q^{2}-\gamma^{3}$ を 0 に収束させて $K_{4}$ を求める方法とが可能である.

$q^{2}-\gamma^{3}=0$ の式で直接演算する場合, $K_{4}$ の 6 次方程式 を解くことになり実用的でないので， $q^{2}-\gamma^{3}$ をに収束 させて求める方法を用いた。

分子量 $M$, 粘性率 $\eta$ から求めた $K_{1}, K_{2}, K_{3}, K_{4}$ につい て $q^{2}-\gamma^{3}$ を求め $q^{2}-\gamma^{3}>0$ なら $K_{4}$ 減少, $q^{2}-\gamma^{3}<0$ なら $K_{4}$ を増加させる方法で $K_{4}$ を修正し， $q^{2}-\gamma^{3}<0$ で 0 に できるだけ近づける方法をとった。つぎに式(4)，式(9) の接続点 $\Delta Z=X_{3}$ は, $q^{2}-\gamma^{3}$ が零になれば cardano の式 が適用できるが，そらはならないので newton 法で求め る方式とした。

以上の方法によって任意の気体の分子量 $M$ と粘性率

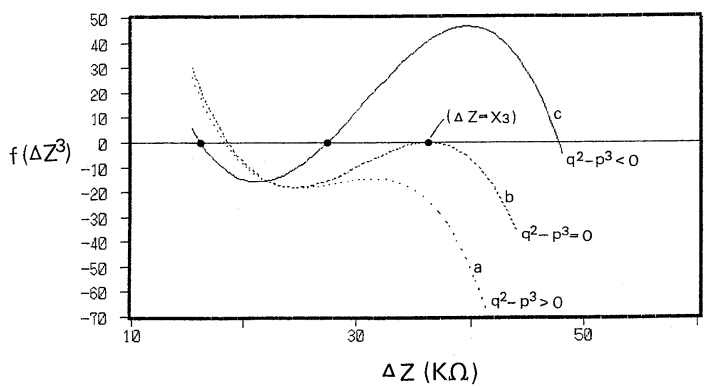

Fig. 10. Relationship between approximation function $f(\Delta Z)$ corresponding to pressure and $\Delta Z$ for different Cardano formula conditions. 


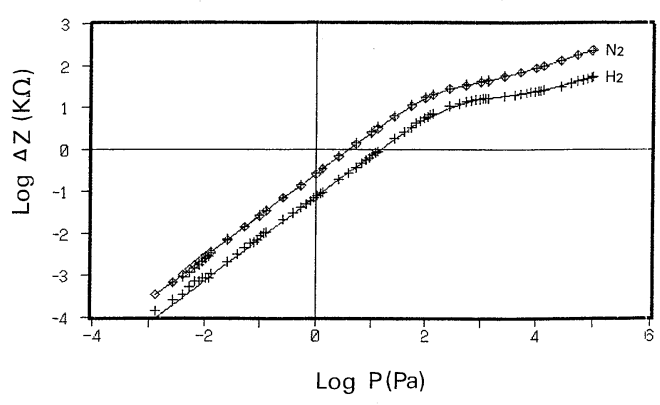

Fig. 11. Comparison of the calculated and measured values of the impedance increment $\Delta Z$ as a function of the pressure. Solid lines are given by calculation, and the plots by measured values.

$\eta$ を入力することによって $K_{1}, K_{2}, K_{3}, K_{4}$ の值を決定出 来ると共に分子流領域の (4) 式と粘性流領域の (9) 式の接 続点 $X_{3}$ が決定される.

$X_{3}$ は測定した共振インピーダンス $Z$ と固有インピー ダンス $Z_{0}$ の差 $\Delta Z$ に対する值であるから, 測定で求め た $\Delta Z$ の值と上記で求めた接続点 $X_{3}$ の值の大小判定を 行い, $\Delta Z \leqq X_{3}$ の場合は測定している圧力の領域は分子 流および中間流領域にあることを意味するので(4)式か ら圧力 $P$ を演算する. $\Delta Z>X_{3}$ の場合は測定している圧 力が粘性流領域にあることを意味するので(9)式から圧 力 $P$ を演算する。 これにより分子流から粘性流領域ま でを連続して近似できることになる。

以上を整理すると, 分子量 $M$, 粘性係数 $\eta$ が入力さ れた時点で(5)，(6)，(10)，(11) 式より $K_{1} \sim K_{4}$ を求め, (4), (9) 両式が接続できるよう修正し, 両式の接続点 $\Delta Z=X_{3}$ を求めることになる。 これによって分子流から 粘性流まで連続した近似ができた。この計算に 8 bit イクロプロセッサ HD6303で約700 msec を要した。通常 の圧力計算は $10 \mathrm{msec}$ 程度で終了し, 実用的な計算速度 が達成された。

Fig. 11, Fig. 12は $N_{2}$ と $H_{2}$ に対して今回の方式で算 出した校正曲線（実線）と実測值（ に圧力計算値の実験值に対する誤差を示した． $10^{-2} \mathrm{~Pa}$ 以上の圧力では $10 \%$ 以内で一致している， $H_{2}$ やXeの ような校正曲線が大きく異なる気体でも20\%以内の䛊差 で校正曲線が計算によって求めることができた。

\section{6. 水素の自動判定}

水晶振動子共振周波数は, 分子流領域では殆ど変化が ないが，粘性流領域での圧力依存性としては次の（14）式 が成立する ${ }^{1)}$.

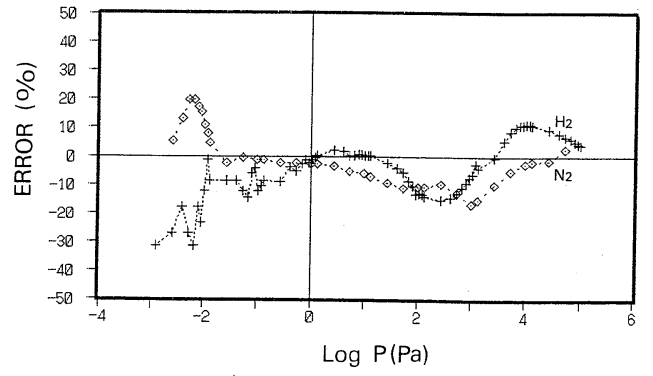

Fig. 12. Error in pressure estimation vs pressure.

$$
\Delta \omega / \omega_{0}=-\frac{1}{2 m}\left(3 \pi R^{2} \sqrt{\frac{2 \eta \rho}{\omega}}+\frac{2}{3} \pi R^{3} \rho\right)
$$

特に大気圧近傍では括弧内第 2 項が支配的であり, 共 振周波数の変化分は注ぼ圧力に比例することが実験と理 論の両面から確かめられている.

一方大気圧近傍に拈ける共振周波数の気体種依存性は (14)式より

$$
\begin{aligned}
\Delta \omega / \omega_{0} & =-\frac{1}{2 m}\left(\frac{2}{3} \pi R^{3} \rho\right) \\
& =-\frac{1}{4} \frac{\rho}{\rho_{0}}
\end{aligned}
$$

$\left(m=(4 / 3) \pi R^{3} \rho_{0}, \rho_{0}\right.$ は水晶の密度 $)$

ここで, 気体密度 $\rho$ は分子量に比例するので

$$
\Delta \omega / \omega_{0} \propto M
$$

が成立する.

従って, 大気圧近傍では水晶振動子の共振インピーダ ンスと共振周波数の変化を計測することによって気体種 の特定が可能である.

本真空計は軽質量気体の感度が低いので $N_{2}$ や空気に 対する圧力表示の状態で $H_{2}$ を導入するとき, 表示は大 気圧にも拘らず容器内は十気圧以上に達する可能性があ る. 我々はこの過圧を未然に防ぐために共振周波数の圧 力依存の特性を $H_{2}$ の自動判定機能に利用することとし た。

共振周波数の温度依存性はすでにセンサー温度の検出 に使用し, 温度変化による共振インピーダンスの補正に 利用しているが, 温度の変化による共振インピーダンス 変化が圧力測定に影響を与える圧力領域は10 Pa 以下で あり, $10 \mathrm{~Pa}$ 以上の圧力領域では温度補償の必要はな い. 従って共振周波数の変化は $10 \mathrm{~Pa}$ 以下の圧力領域で は温度補償のための温度検出, $10 \mathrm{~Pa}$ 以上の圧力領域で は気体種 $\left(H_{2}\right)$ の特定に用いた。

$H_{2}$ の自動判定機能は水晶振動子の $\Delta Z$ を測定すると 同時に水晶振動子の共振周波数 $f$ の変化 $\Delta f\left(=f-f_{0}\right)^{9}$ を 測定し, 両者の相関を調べることによって, 被測定気体 


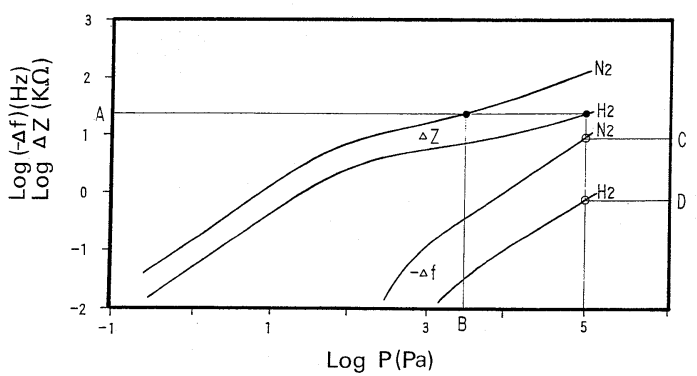

Fig. 13. Pressure dependence of resonant frequency $f$ and increment $\Delta Z$ of resonant impedance for nitrogen and hydrogen gases.

が $H_{2}$ であると判定された場合には，自動的に分子量 $M$ と粘性率 $\eta$ を水素の值に変更する。（ここで $f$ は任意 の圧力での共振周波数, $f_{0}$ は圧力が $1 \mathrm{~Pa}$ 以下での共振 周波数）すなわち, Fig. 13のよう飞 $H_{2}$ の場合, 圧力 $1 \times 10^{5} \mathrm{~Pa}$ でのインピーダンス $\Delta Z$ は $22.3 \mathrm{k} \Omega$ ( $A$ 点),$N_{2}$ の場合は同じ $\Delta Z$ での圧力表示は $2.5 \times 10^{3} \mathrm{~Pa}(B$ 点 $)$ と なる. 一方, 圧力上昇前の水晶振動子共振周波数との差 $\Delta f$ は $N_{2}$ の場合, $-0.75 \mathrm{~Hz}$ ( $C$ 点), $H_{2}$ の場合, -0.33 $\mathrm{Hz}$ ( $D$ 点) となる. 従って, $N_{2}$ 表示のまま $H_{2}$ を真空 容器に導入した場合でも $\Delta Z$ が $22.3 \mathrm{k} \Omega$ での $\Delta f$ を測定す ることにより， $H_{2}$ か否かの判定が可能になった.

Fig. 14に本真空計が $H_{2}$ 気体を自動的に検知し $H_{2}$ を $1 \times 10^{5} \mathrm{~Pa}$ まで導入した例を示す.

本真空計を真空容器に取付け, 容器を $1 \times 10^{-4} \mathrm{~Pa}$ 以 下に排気した後, 排気系を切り離し容器に $H_{2}$ を導入し た時の真空計の表示 $(P)$, 周波数 $(f)$, そしてインピ 一ダンス変化量 $(\Delta Z)$ を時間経過で示した. $H_{2}$ 導入に よって $\Delta Z$ が $0.1 \Omega$ から増加, それに伴い表示も $0.01 \times$ $10^{-1} \mathrm{~Pa}$ から増加し, 表示が約 $1 \times 10^{2} \mathrm{~Pa}$ で $f$ も 32382.4 $\mathrm{Hz}$ から減少する。そして $\Delta Z$ が約 $48.5 \mathrm{k} \Omega, f$ が 32382.0 $\mathrm{Hz}$ の時点で導入している気体が $H_{2}$ であることを判定 し, 分子量 $M$ と粘性率 $\eta$ の值を $H_{2}$ の値に修正するこ とによって $N_{2}$ 表示 $2.7 \times 10_{2} \mathrm{~Pa}$ から $H_{2}$ 表示 $6.7 \times 10^{4} \mathrm{~Pa}$ となり過圧することなしに $1 \times 10^{5} \mathrm{~Pa}$ まで $H_{2}$ を導入す ることがでさた。

つぎに圧力・ガス種共に未知の真空装置に本真空計を 取り付けて作動した場合の圧力表示及びセンサ一温度表 示は, 共振インピーダンス変化からガス種を $N_{2}$ と仮定 し圧力を計算, $10 \mathrm{~Pa}$ 以下の領域では共振周波数から七 ンサー温度を計算しそれぞれ表示することができる。

ここで未知ガスが最も感度の低い $H_{2}$ でも， $N_{2}$ 仮定で $10 \mathrm{~Pa}$ 以下であれば $H_{2}$ 圧力として約 $1 \mathrm{~Pa}$ 以下の圧力と なり, 压力による周波数の変化がない領域でありセンサ 一温度は正確に求まる。圧力が大気圧近傍では圧力によ

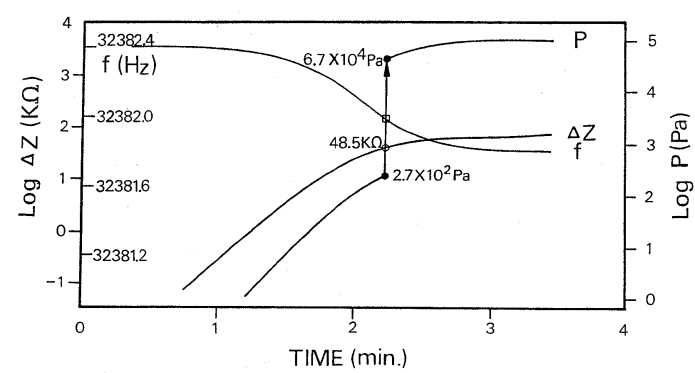

Fig. 14. Variation of the frequency, impedance and pressure indication during introduction of hydrogen after evacuation.

って周波数が変化するため, センサー温度は正確に求め られない。( $\left(N_{2}\right.$ で数 ${ }^{\circ} \mathrm{C} の$ 誤差となる $)$

今回実用的にも有益で, $N_{2}$ と比較して周波数の変化 の差が最も大きい $H_{2}$ について試みたが，原理的には周 波数の計測精度を向上することによって他の気体につい ても $H_{2}$ 同様の判定が可能である.

\section{7. むすび}

水晶振動子の共振インピーダンスと周波数の気体の圧 力に対する変化の特性が理論的に解明されていることに 着目して, 高感度, 高機能水晶真空計の開発を進めた。

温度センサー機能を有する高感度, 低ノイズの水晶振 動子採用により, 振動子自身の温度を $0.03^{\circ} \mathrm{C}$ 分解能で測 定し, 温度変化による $Z_{0}$ を約 $0.2 \Omega$ の分解能で補償する ことによって圧力測定下限を $1 \times 10^{-3} \mathrm{~Pa}$ まで拡張し， $10^{-2} \mathrm{~Pa}$ 領域の圧力を安定に測定できた。 また，圧力に 上る共振インピーダンス变化の気体種依存性を理論式に 基づいて計算するマイクロプロセッサ用データ処理法を 開発し，圧力 $P$ を測定した $\Delta Z$ から 8 bit マイクロプロ セッサを用いて計算するのに約 $10 \mathrm{msec}$ といら実用的演 算時間を達成することができた。

気体種に対する感度補正に関しては，測定気体の分子 量 $(M)$ と粘性係数（）とを入力することにより，そ の気体の圧力を直接表示から読み取ることが可能になっ た.さらに，共振インピーダンスと共振周波数の気体種 依存性を利用する大気圧近傍での $H_{2}$ の自動判定機能の 付加によって, 真空装置への導入時に起こりうる過圧を 未然に防ぐことも可能となった.

水晶真空計は各種気体圧力を広い圧力範囲で, 実用的 な精度で測定できることから，低中真空領域の真空計と して有用である。ささらに，小型で低消費電力であること と温度変化に対する自動補正法を開発したことにより， B-A ゲージのよらな熱陰極を持つ電離真空計球の中に 水晶真空計を組み込み, 1 つの真空計球で大気圧から超 
高真空領域まで測定できる真空計の実現も可能となっ た。

尚，ここに報告した高感度，高機能水晶真空計の技術 は現在製品化が注ぼ完了している.

終りに，本真空計開発に際して御助言をいただいた電 子技術綜合研究所の国分清秀氏，東北工業技術研究所の 小野雅敏氏に深く感謝いたします。

\section{[文献]}

1）国分清秀，平田正紘，小野雅敏，村上 寛，戸田義 継：真空 29 (1986) 101.

2）小林太吉, 北條久男, 永井 充 : 第33回真空に関す る連合講演会講演予稿集 (1992. 日本真空協会).

3) M. Ono, M. Hirata, K. Kokubun, H. Murakami, H.
Hojo, H. Kawashima and H. Kyogoku: J. Vac. Sci. Technol. A4 (1986) 1728.

4) T. Kobayashi, H. Hojo and M. Ono, Vacuum, 44 (1993) 613.

5) M. Hirata, M. Ono, K. Kokubun, M. Abe, N. Maruno, K. Shimizu and T. Ogawa: J. Vac. Sci. Technol. A5 (1987) 2393.

6) M. Ono, M. Hirata, K. Kokubun, H. Murakami, F. Tamura, H. Hojo, H. Kawashima and H. Kyogoku: J. Vac. Sci. Technol. A3 (1985) 1746.

7) M. Hirata, K. Kokubun, M. Ono and K. Nakayama: J. Vac. Sci. Technol. A3 (1985) 1742.

8) K. Kokubun, M. Hirata, M. Ono, H. Tanaka, R. Aida and A. Nagata: Vacuum 40 (1990) 521.

9) K. Kokubun, M. Hirata, M. Ono, H. Murakami and Y. Toda: J. Vac. Sci. Technol. A3 (1985) 2184. 